\title{
Karl-Georg Pfändtner (ur.): Gold und Bücher lieb ich sehr ... 480 Jahre Staats- und Stadtbibliothek Augsburg. Katalog zur Cimelien-Ausstellung vom 19. Oktober bis 15. Dezember 2017
}

\section{Luzern: Quaternio Verlag, 2017, 240 strani}

$\mathrm{Na}$ naključno odprtih straneh publikacije, ki je $\mathrm{v}$ podnaslovu opredeljena kot razstavni katalog, so nekateri pogledi na knjige in s knjigami povezane predmete presenetljivi: $\mathrm{v}$ njih vidimo sestrske stvaritve s tistimi iz slovenskih javnih knjižnic in arhivov. Seveda ima vsaka knjižnica svoje dragocenosti in posebnosti, noben fond nima zrcalne podobe $\mathrm{v}$ drugem mestu, a marsikateri pri nas hranjeni rokopis, prvotisk in grafika so s svojo vsebino in likovno podobo potrditve stikov, ki so jih generacije iz dežel Kranjske, Štajerske in Koroške od približno 10. do 16. stoletja vzdrževale s švabskim Augsburgom in bližnjimi kraji. Ob delih iz naših zbirk je bilo mogoče ničkolikokrat zapisati, da gre za stvaritve iz južne Nemčije ali celo Augsburga, vendar so se take ugotovitve osredotočile na pozno 15. stoletje, ta katalog pa dokazuje, da je zlitost literarnega in likovnega med obema deželama potekala vsaj od ok. 1200 dalje. Da je knjižnica hranišče spominov, ki jih brez materializirane oblike ne bi imeli, je jasno, a dela je treba dobiti pred oči.

$\mathrm{K}$ vtisom, katere knjižne enote se povezujejo v ustvarjalno skladnost, se bom vrnila, sedaj pa nekaj okvirnih misli. Današnja Staats- und Universitätsbibliothek Augsburg, ki je od leta 2012 regionalna državna knjižnica, je bila ustanovljena leta 1537 kot mestna knjižnica (dobro se je spomniti, da je Ljubljana približno takrat, leta 1569, dobila svojo stanovsko knjižnico, ki bi lahko prihodnje leto praznovala 450 obletnico). Jedro knjižnice so bili rokopisi in tiski, ki so jih menihi karmeličanskega samostana sv. Ane prepustili mestu, sicer pa so se vanjo zlivale osebne knjižnice velikih humanistov in raziskovalcev, npr. diplomata in humanista Antoniosa Eparchosa ter cesarskega svetnika in humanista Konrada Peutingerja, dobila je grške rokopise kardinala Karla Borromejskega itd. Tako kot številne druge državne in pod varstvom aristokracije razvijajoče se knjižnice se je augsburški fond bistveno povečal ob sekularizaciji samostanov; res so takrat, leta 1806, največ knjig odpeljali v München, a v Augsburgu so smeli obdržati vsaj knjige iz »svojih « cerkva in samostanov, tako da je samostojna knjižnična palača (zgrajena 1563) pokala po šivih, nova palača s pročeljem v baročnem slogu pa je leta 1893 sprejela večji del fondov. 
Lanska razstava je bila samo eden od projektov, posvečenih jubileju, saj je bil za to priložnost zasnovan širši javnosti namenjen bogat katalog na 240 straneh. $O$ razpoloženju augsburških obiskovalcev zgovorno priča podatek, da je katalog pošel. $\mathrm{V}$ njem so predstavljene cimelije, ki jih je v Augsburgu 116, od tega je 47 enot iz srednjega veka. Oznaka »cimelija« je termin zgodnjega 19. stoletja; leta 1808 je Martin Schrettinger iz Dvorne biblioteke München zapisal (takrat že širše sprejeto) definicijo, da so cimelije

- $\quad$ knjižne enote, ki izstopajo zaradi posebno dragocene vezave;

- $\quad$ rokopisi, ki jih krasijo odlične miniature znamenitih mojstrov ali pa imajo pomembne grafične odtise v bakrorezni in lesorezni tehniki;

- dela, ki so napisana, natisnjena ali vdolbena na posebno redko pisno osnovo - dovoljeno jim je priključiti enkratna kitajska dela;

- dela, ki so dragocena zaradi izjemne starosti ali redkosti oz. obojega. To so rokopisi in tiski, v katerih so dela znamenitih mož, prvotiski, poznejši tiski, ki so zelo redki, exemplaria unica, razkošne izdaje. ${ }^{1}$

Vse to je predstavljeno v uvodnem besedilu in 77 kataloških enotah, ki se oblikovno ujemajo s konceptom velikih razstav na Bavarskem, tako da je tudi vizualno ustvarjena kontinuiteta tako rekoč državnega programa, ki izpostavlja pisno, materialno, kulturno in intelektualno prisotnost $\mathrm{v}$ katerikoli obliki varovanih in razstavljenih objektov. Že prvi poudarek, ki ga zastopajo dragocene vezave, je imenitno prisoten v obliki reprodukcije platnic na Koranu iz 16./17. stoletja v malone naravni velikosti in uporabljenih kot predlist kataloga (žal nas hkrati spomni, da je knjigoveštvo kot žlahtna umetnost $\mathrm{v}$ zadnjem času ogromno izgubilo in da postajamo neobčutljivi na sedaj samoumevne zmazke, zlepljene liste, ki jih izvržejo stroji). Navedbi, da med cimelije spadajo dela, napisana ali vdolbena na redko ali nenavadno osnovo, ustreza sorazmerno dobro ohranjena ploščica $\mathrm{z}$ ulitim voskom (gre za »list « iz knjige voščenih tablic) s konca 14. ali začetka 15. stoletja z gospodarskimi noticami o oddaji moke, lesa itd. (kat. 9). Lesorezne in bakrorezne matrice niso prav pogoste, zato je izbor primerno dragocen, ker posreduje pripravljalne in vmesne faze (kat. 24-28) ali pa doživimo matrico in odtis (tudi kat. 32, Gilgengart, ki je oblika molitvenika). Čudoviti so islamski rokopisi, grška dela ter Utamarovi, Hokusaijevi, Masayoshijevi itd. lesorezi. Paša za oči in duhà - a kaj naj bi cimelije sicer bile?

Po pričakovanem pravilu, da izbrano gradivo sledi logiki istovrstnosti in časovnega zaporedja, so reproducirani in zvečine opisani rokopisi, zgodnji umetniški tiski in knjižni tiski, avtografi znamenitih oseb (Martin Luther, Philipp Melanchton, Leopold Mozart, Konstanze Mozart, Johann Wolfgang Goethe in drugi) ter japonskih risb in tiskov.

1 Prosti prevod navedb v katalogu, 21-22. Izvirnik je bil natisnjen leta 1808: Versuch eines vollständigen Lehrbuchs der Bibliotheks-Wissenschaft, 1. knjiga. 
Samo s svojega vidika srednjeveških knjig, kjer sledim razvoju tja do tridentinske prelomnice, želim opozoriti na nekaj izstopajočih enot, ki so povezane z našim gradivom. Tak je (kat. 1) iluminirani psalter iz zgodnjega 13. stoletja. Gre za v estetiki le malo starejši kodeks, kot sta lepa knjigoveška fragmenta Tobijeve knjige iz knjižnice ljubljanskih frančiškanov: ${ }^{2}$ dober občutek je, ko najdemo potrditev, da se naše gradivo uvršča med odlične spomenike južnonemške knjižne umetnosti pozne romanike oz. zgodnje gotike. V tem katalogu je presenetljiva odsotnost iluminiranih rokopisov med letoma 1200 in 1450, kar pa je posledica zgodovinskih okoliščin in preselitve teh rokopisov ( $\mathrm{v}$ teku sekularizacijskih odločitev) v München, tako da augsburško rokopisno prizorišče zaživi v vznemirjenem ritmu sredi 15 . stoletja $\mathrm{z}$ deli iz skriptorija samostana sv. Ulrika in Afre ter ob eruptivnem nastopu mestnih rokopisnih delavnic Heinricha Molitorja, Johannesa Bämlerja, Leonharda Wagnerja in drugih (kat. 3, 5, 6, 7, 10, 11, 12). Ob nekaterih je treba postati: liturgični psalter (kat. 3), ki ga je bogato poslikal Georg Beck in kadele dodal Conrad Wagner - dve znameniti osebi na odru izginjajoče rokopisne umetnosti -, je z ornamentalnimi obrobami (ne scenskimi inicialami) prepoznaven tudi v gradivu iz slovenskih zbirk, npr. v fragmentu antifonarja iz Sadnikarjeve zbirke v Kamniku in fragmentu graduala iz Arhiva Republike Slovenije. ${ }^{3}$ Ti razstavni objekti niso bili dosledno izbrani zaradi vrhunskega estetskega dosežka, ampak tudi zaradi drugih ozirov: tàko vrednost ima npr. najstarejši prevod Nove zaveze v nemščino iz ok. 1350, pa tudi besedila mestne kronike in lokalnega procesionala; posebej odlična je rokopisna genealogija družine Hainhofer (ok. 1626): že na ovitku kataloga vidimo del dvostranske kompozicije pava, ki na razprtem repu daje prostor številnim grbom družin, prednicam Philippa Hainhoferja in njegove žene Regine Waiblinger - v ozadju pa je imenitna veduta Augsburga (kat. 18) itd. Mimogrede izvemo še nekaj detajlov o Hainhoferjevi zbirki umetnin in raritet, ki ga je postavila ob bok visokemu plemstvu.

Zanimivo je spremljati harmonično oblikovane rokopisne strani. Od izbire formata, črk in tintnih odtenkov ter od postavitve na folij je imel vsak detajl vlogo v celoti. To je bil čas, ki ga zaznamuje izpiljenost rokopisnega znanja, kar se je prelilo $\mathrm{v}$ tiske. $\mathrm{V}$ javnih zbirkah po Sloveniji lahko najdemo večje število rokopisov in fragmentov, ki so očitno nastali v istih ateljejih. - Nekateri objekti so vznemirljiva dokazila povezav med estetiko južnonemškega prostora in dosežki iz burgundskih krajev (s skupino iluminiranih rokopisov v slogu šole Ghent-Brugge), ki poskuse iluzij (trompe-l'oeil) prenašajo na proste robove protokolarnih rokopisov (kat. 6). In lepo je videti zasedanje augsburških cehov: upodobitev je filmično bogata in dokumentarno

2 Fragmenta s signaturo I/66 sta reproducirana v: Golob, N., S črnilom in zlatom, Ljubljana 2017, kat. 24.

3 Sadnikarjevo zbirko rokopisnih fragmentov hranijo v Zgodovinskem arhivu Ljubljana, gradualni fragment pa je - z detajlom kadele - objavljen v Golob, N., Srednjeveški rokopisi in rokopisni fragmenti: Arhiv Republike Slovenije, Ljubljana 2018, kat. 84. 
pomembna. Poleg (običajnih) liturgičnih glasbenih rokopisov jemlje sapo Lassov Magnificat, ki je popolna risarska mojstrovina.

Prvotiski, v katerih so dobile primeren delež lesorezne ilustracije in so jih nato kolorirali, so v augsburški knjižnici bogato zastopani, zato se mi zdi vredno opozoriti, da je prav dodana barvna žlahtnost povzdignila tiskano delo: prefinjeno koloriranje je izvod, enega od več sto enakih v posamezni nakladi, spremenilo v enkratno doživetje. Ob bok tem imenitnostim naj vnovič opozorim, da je kolorirana Nemška biblija (NUK, sign. 5526) odličen dosežek, boljši od reproducirane vedute Augsburga iz Schedlove Svetovne kronike. Nedvomno so paša za oči heraldične in aristokratske predstavitve ter prelesten tisk viteške pesnitve Theuerdanka Maksimilijana I., kjer vsak koloriran lesorez spremeni stran v sliko na pergamentu, ki ji je dodanih nekaj vrstic besedila.

Med prvotiski bo za poznavalce črne umetnosti zanimiva primerjava $\mathrm{z}$ Gutenbergovim natisom Donatove Ars minor (kat. 60c), ker komentar ob reprodukciji ter navedena literatura ne omenjata Costerjevega tiska, ki je - prav tako fragmentarno - ohranjen v NUK-u. ${ }^{4}$ Nekaj pred otvoritvijo razstave so javnost obvestili o nenadejani najdbi fragmenta iz Gutenbergove 42-vrstične Biblije: ker je v augsburški knjižnici iz časa pred 1800 kakih 120.000 enot, se je knjiga v nekoliko obdrsani pergamentni vezavi izmuznila podrobnejšemu pogledu. Pristojni kustos, dr. Wolfgang Mayer, je postal pozoren na inicialo s sv. Janezom, avtorjem Razodetja, ker je na fragmentu natisnjen začetek Apokalipse. Ta izvod Gutenbergove Biblije so okrasili v ateljeju češko šolanega knjižnega slikarja, ki je vodil t. i. atelje »Pfauenwerkstatt« (kat. 60a).

Ne vem, ali je pri nas znan rokopisni zbornik družine Herberstein, ki vsebuje nekaj listin oz. prepisov (leta $1522 \mathrm{z}$ dovoljenjem za izboljšanje grba) in med drugim prošnjo Žige Herbersteina za upokojitev (1542) z nedvoumnim podpisom »In hoffnung Irer lieb In trewen Sigmundt von Herberstein «. Rokopis je zbornik, ki je delno nastal leta 1419, zvečine pa med letoma 1548 in 1550 (kat. 40).

Na kratko je mogoče povzeti dragoceno darilo kolega Pfändtnerja ter dodati nekaj vprašanj našemu knjižnemu okolju v naslednjih alinejah:

- Hvaležni moramo biti za živahen znanstveni dialog in kulturni spomin: kar je natisnjeno, je lahko vedno med nami, za naše raziskave in korake naprej. Ta katalog je vnovič pokazal, kako enakovreden in kakovosten je bil pretok misli in idej v tem povezanem vzhodnoalpskem prostoru.

- Nobene priložnosti, da vrnemo v spomin vse imenitne dosežke preteklosti in se zavemo, kako dragocena so ta sporočila za nas, ker smo zrasli na

$4 \mathrm{Za}$ (domnevno) Costerjeve fragmente Donatove Ars minor gl. Svoljšak, S., Kratka predstavitev zbirke prvotiskov NUK, v: Črna umetnost v barvah, Ljubljana 2017, str. 12 in slika na str. 13 s starejšo literaturo. 
intelektualno in umetnostno enakovrednem substratu, ne smemo zamuditi. Posebej ne v tem ohlapnem času politične dezorientiranosti, ko ob pogostem ponavljanju stališč o kulturni drobnosti Slovenije naši predstavniki v javnem življenju kažejo svojo zanikrno izobrazbo.

- Prav tako nam nobena publikacija iz uglednih evropskih zbirk, pospremljena s slovesnostmi, ne sme vzbuditi občutka, da zaostajamo - ne, le predstaviti se moramo tudi mi sami doma in onkraj političnih meja. Katalog dragocenosti iz Augsburga je lahko v tem pogledu sijajen učbenik.

- Hvaležni bi morali biti za zamisli, ki jih sproža augsburški katalog: mar nimamo v Šolskem muzeju krasnih voščenih tablic, mar nimamo v knjižnici Nadškofijskega arhiva imenitnih vezav, mar nimamo v NUK-u briljantnih tiskov, ali ni Herbersteinova knjiga na Ptuju imenitnejša od tiste iz Oxforda, ali niso karolinški fragmenti iz Zgodovinskega arhiva povsem enkratni, ali niso Erbergove vezave iz Narodnega muzeja čudovit prispevek k predstavitvi erudicije vsega srednjeevropskega prostora? Slovenski prostor je nabit s cimelijami. Prav zares.

- Vprašanje (na katero bi znal odgovoriti Martin Krpan) pa se nanaša na institucije, ki imajo platno in škarje $\mathrm{v}$ rokah, premorejo pa tudi poznavalce in izjemne raziskovalce: se znamo organizirati in nastopiti z enako zamislijo? Tisti frankfurtski sejem, ko je posebna gostja Slovenija, bi bil kar primerna priložnost. ${ }^{5}$

5 Katalog Gold und Bücher lieb ich sehr ... je od oktobra 2018 dosegljiv v knjižnici oddelka za umetnostno zgodovino. 